\title{
SALINE STRESS EFFECT ON COWPEA BEANS GROWTH UNDER BIOFERTILIZER CORRECTION
}

\author{
EFEITO DO ESTRESSE SALINO NO CRESCIMENTO DO FEIJÃO-CAUPI SOB A \\ CORREÇÃO DE BIOFERTILIZANTE
}

\section{Ednângelo Duarte PEREIRA¹; Albanise Barbosa MARINHO²; Elísia Gomes RAMOS²; Chrislene Nojosa Dias FERNANDES ${ }^{3}$; Francisca Robevania Medeiros BORGES²; Jilson de Nazaré José ADRIANO²}

\begin{abstract}
1. Mestrando, Departamento de Fitotecnia, Universidade Federal de Viçosa, Campus Universitário, Viçosa, MG, Brasil, ednangeloduarte@gmail.com; 2. Instituto de Desenvolvimento Rural/Universidade da Integração Internacional da Lusofonia AfroBrasileira, Redenção, CE, Brasil; 3. Doutoranda, Departamento de Engenharia Agrícola, Universidade Federal do Ceará, Campus do
\end{abstract} Pici, Fortaleza,CE, Brasil.

\begin{abstract}
New strategies to increase growth and food crops productivity in saline soils are priorities in the research. The experiment was carried out in a pot to investigate the growth of cowpea cv. Canapu in response to saline stress under the correction of a mixed biofertilizer. Five irrigation water salinity levels and three doses of the mixed biofertilizer were tested, with four replicates at each level. The increase in salinity level resulted in reductions in stem diameter, leaves number, shoot biomass and roots. The mixed biofertilizer use was able to minimize the effect of salinity in all analyzed variables, improving the cowpea growth and development, protecting from saline stress negative impacts. In addition, the mixed biofertilizer use may be an option to improve crop growth and productivity in salt affected soils.
\end{abstract}

KEYWORDS: Environmental stress. Water quality. Vigna unguiculata.L. Walp.

\section{INTRODUCTION}

Vigna unguiculata L. Walp is one of the main economically planted crops, being a cereal used as food for people and animals, with high nutritional value (QADOS, 2011).

It's considered moderately tolerant to salinity and may be cultivated in arid and semi-arid regions, such as the Brazilian northeast, which is limiting to other species. In these regions, most crops are grown under irrigation and inadequate irrigation management leads to secondary salinization, affecting $20 \%$ of irrigated land worldwide (GLICK et al., 2007; SHRIVASTAVA; KUMAR, 2015).

Salinity may affect plants in various ways such as drought stress, ionic toxicity, nutritional disorders, oxidative stress, altered metabolic processes, membrane disorganization, and reduced cell division and expansion (ZHU, 2007; SIDARI et al., 2008; MUSCOLO et al., 2013).

A saline soil is defined when the electrical conductivity (EC) of the saturation extract (CEe) in the root zone exceeds $4 \mathrm{dS} \mathrm{m}^{-1}$ (approximately 40 $\mathrm{mM} \mathrm{NaCl}$ ) at $25{ }^{\circ} \mathrm{C}$ and exchangeable sodium of $15 \%$, reducing yield of most of the plants grown in this CEe (MUNNS, 2005; JAMIL et al., 2011).

About 20 percent of total cultivated and 33 percent of irrigated farmland worldwide is affected by high salinity (SHAHBAZ; ASHRAF, 2013). Salinized areas increase at a rate of $10 \%$ a year due to low rainfall, high surface evaporation, rocks weathering, saltwater irrigation and poor cultural practices, which can result in more than 50\% salinized arable land by 2050 (JAMIL et al., 2011).

A biofertilizer is any substance or microorganism applied to plants with the aim of improve nutritional efficiency, tolerance to abiotic stress and/or quality characteristics of the crop, regardless of its nutrient content (DU JARDIM, 2015). This definition represents the clearest and most concise way to define biofertilizers. Currently, there are several biofertilizers, both industrial produced and those produced from waste. The latter are prepared with animal, vegetable and agroindustrial residues applied via soil, via irrigation systems or spread on the plants (YAKHIN et al., 2017).

The relevance of the liquid biofertilizers use as management practice in the form of simple or enriched microbial ferments is in the quantitative, diversity and in the nutrients availability by the biological activity, since these substances increase the efficiency of the nutrients use, reduce fertilizer consumption, stimulate plant development and growth (CALVO et al., 2014; HALPERN et al., 2015) and counterbalance stress factors, eventually 
increasing crop quality and productivity (VAN OOSTEN et al., 2017).

The biofertilizer, when applied via soil in liquid form, improves the water infiltration rate and releases humic substances in the soil, increasing the plants osmotic adjustment by the accumulation of these substances, facilitating the water and nutrients absorption in saline environments (AYDIN et al., 2012; SOUTO et al., 2013).

Limited freshwater, growing food needs, the climate change pressure, and the land available reduction for cultivation are threats to agricultural sustainability (SHAHBAZ; ASHRAF, 2013). Practices for managing the saline water resources use may be an important resource for water scarcity (ZAHIR et al., 2008).

The aim of this study was to evaluate the salinity effect on the $V$. unguiculata vegetative growth, with and without mixed biofertilizer applications in saline soils.

\section{MATERIAL AND METHODS}

The work was carred out at the Piroás Experimental Farm, belonging to the Universidade da Integração Internacional da Lusofonia AfroBrasileira (UNILAB), Piroás/ Redenção - Ceará, Brazil (04¹5'55'S, 38 $\left.79^{\prime} 37^{\prime \prime} \mathrm{W} ; 240 \mathrm{~m}\right)$. The region climate is hot, dry semi-arid, with low cloudiness, high evaporation pattern and strong insolation (KÖPPEN, 1928). Rainfall is concentrated between January and April with average precipitation between 380 and $760 \mathrm{~mm}$, distributed irregularly during the year (CELENTANO et al., 2017).

$V$. unguiculata $\mathrm{cv}$. Canapu was cultivated in open-air in pots of $39.5 \mathrm{~L}$ in single rows with spacing of $0.5 \times 0.5 \mathrm{~m}$ and planting density of 28,570 plants $\mathrm{ha}^{-1}$. The vessels were filled with a $0.05 \mathrm{~m}$ layer of gravel and a substrate composed of sand and local soil in a 2:1 ratio.

The mean of irrigation water salinity was $0.4 \mathrm{dS} \mathrm{m}^{-1}$, being considered the control treatment. Other concentrations were obtained by the addition of the $\mathrm{NaCl}, \mathrm{CaCl}_{2} \cdot 2 \mathrm{H}_{2} \mathrm{O}$ and $\mathrm{MgCl}_{2} \cdot 6 \mathrm{H}_{2} \mathrm{O}$ salts, in the ratio 7:2:1 (RHOADES et al., 2000). Irrigation was started 15 days after emergence (DAE) and maintained until the end of the cycle by drip irrigation. The irrigation shift was of two days, whose water amount to be applied was calculated according to the evaporation of the class "A" tank.

The experimental design was in randomized blocks in the subdivided plots scheme, with four blocks. The plots were composed of water with five levels of salinity, $0.4 ; 1.4,2.4,3.4$ and $4.4 \mathrm{dS} \mathrm{m}^{-1}$, respectively, without leaching fraction and the subplots consisted of three doses of mixed biofertilizer equivalent to 0,400 and $800 \mathrm{~mL} \mathrm{plant}^{-1}$. Mixed biofertilizer application was manually through graduated containers and divided twice a week, starting at the same irrigation application period. The biofertilizer was prepared with $100 \mathrm{~L}$ of fresh bovine manure, $30 \mathrm{~L}$ of chicken manure and $5 \mathrm{~L}$ of wood ash, diluted in $270 \mathrm{~L}$ of fresh water. The biofertilizer decomposition time was 30 days and monitored daily with $\mathrm{EC}, \mathrm{pH}$ and temperature measurements. Cultural dealings followed the recommendations for the culture.

The biofertilizer after 30 days of decomposition had the following characteristics: $\mathrm{N}$ $=1.20 ; \mathrm{P}=0.38 ; \mathrm{K}=0.03 ; \mathrm{Ca}^{2+}=2.82 ; \mathrm{Mg}^{2+}=0.63$ and $\mathrm{S}=0.01 \mathrm{~g} \mathrm{~L}^{-1} . \mathrm{Na}=611 ; \mathrm{Fe}=91.54 ; \mathrm{Mn}=10$, $56 ; \mathrm{Zn}=6.4$ and $\mathrm{Cu}=3.06 \mathrm{mg} \mathrm{L}^{-1}$.

The stem diameter (DS) and leaves number (NL) were determined every 7 days between 15 and 57 DAE. The stem diameter was measured with digital caliper at the base of the stem $2 \mathrm{~cm}$ from the soil surface. The leaves number was quantified through weekly direct counting. The harvest occurred between 59 and 103 DAE and, at the cycle end, the fresh and dry mass of the underground and abovegorund parts were evaluated.

Fresh mass of aerial part (FMAP) and root (FRM) were determined with precision scale (model S1002 - BEL). Dry mass of aerial part (DMAP) and root (DRM) were obtained by drying in full sun until constant weight.

Statistical analysis, for all observed variables, was performed by analysis of variance $(\mathrm{F}$ test, $5 \%$ significance). When significant, regression analysis was performed. In the regression analysis, the equations that best fit the data were chosen based on the significance of the regression coefficients at the significance level of $5 \%(*)$ by the $\mathrm{F}$ test, and the highest coefficient of determination $\left(\mathrm{R}^{2}\right)$. The software used was ASSISTAT - Statistical Assistance, version 7.7 beta (2016).

\section{RESULTS AND DISCUSSION}

The treatments effects on stem diameter (SD) and leaf number (NL) of cowpea beans as a evaluation times function, salinity levels and mixed biofertilizer doses indicated a significant effect $(\mathrm{p} \leq$ 0.05 ) on the two analyzed variables, with exception of the leaves number that was not significantly affected by the biofertilizer doses. The interaction between the factors was significant $(\mathrm{p} \leq 0.05)$ among all the treatments applied, except for the leaves number where the interaction times and 
mixed biofertilizer doses were not significant (Table $1)$.

The treatments effect on SD and NL of common bean as a evaluation times function, salinity levels and mixed biofertilizer doses suggests that plant growth was variable according to season, salinity level and mixed biofertilizer doses as reported for culture (SOUZA et al., 2014).

Table 1. Summary of variance analysis for stem diameter (SD) and leaves number (NL) of cowpea plants submitted to irrigation with different salinized water levels and mixed biofertilizer doses

\begin{tabular}{llll}
\hline \multirow{2}{*}{ Source of Variation } & \multirow{2}{*}{ df } & Mean squares & NL \\
\cline { 3 - 4 } & & SD & $43.11609^{*}$ \\
\hline Blocks & 3 & $2.60210^{*}$ & $908.62057^{*}$ \\
Epoch (a) & 6 & $80.82617^{*}$ & 8.44498 \\
Error - a & 18 & 0.13123 & $57.80803^{*}$ \\
Salinity (b) & 4 & $4.91688^{*}$ & $39.96648^{*}$ \\
Interaction a x b & 24 & $1.35045^{*}$ & 6.20613 \\
Error - b & 84 & 0.34759 & $11.19299^{\text {ns }}$ \\
Biofertilizer (c) & 2 & $8.36000^{*}$ & $5.90504^{\text {ns }}$ \\
Interaction a x c & 12 & $0.74877^{*}$ & $18.76311^{*}$ \\
Interaction b x c & 8 & $1.21299^{*}$ & $5.12509^{\text {ns }}$ \\
Interaction a x b x c & 48 & $0.15352^{*}$ & 6.55610 \\
Error - c & 210 & 0.41337 & - \\
Total & 419 & - & \\
icant at 5\% by the F test; (ns) not significant by the F test; df - Degree of freedom.
\end{tabular}

* significant at $5 \%$ by the $\mathrm{F}$ test; (ns) not significant by the F test; $\mathrm{df}$ - Degree of freedom.

The stem diameter as a function of days after emergence, for each salinity and mixed biofertilizer level doses were adjusted to the increasing linear model. The largest stem diameter $(6.74 \mathrm{~mm})$ occurred at $57 \mathrm{DAE}$ at $0.4 \mathrm{dS} \mathrm{m}^{-1}$ and decreased with increasing salinity (Figure 1A-B).

The largest stem diameter at $0.4 \mathrm{dS} \mathrm{m}^{-1}$ is due to the potentially toxic ions $\left(\mathrm{Na}^{+}\right.$and $\left.\mathrm{Cl}^{-}\right)$low concentration in water and foliar tissues, without affecting the photosynthetic system and ensuring the $\mathrm{CO}_{2}$ diffusion into the cells and consequently not harming the plant growth (LACERDA et al., 2003). The $V$. unguiculata reduction stem diameter occurred when irrigated with water at $1.55 \mathrm{dS} \mathrm{m}^{-1}$ (PRAZERES et al., 2015). V. unguiculata,

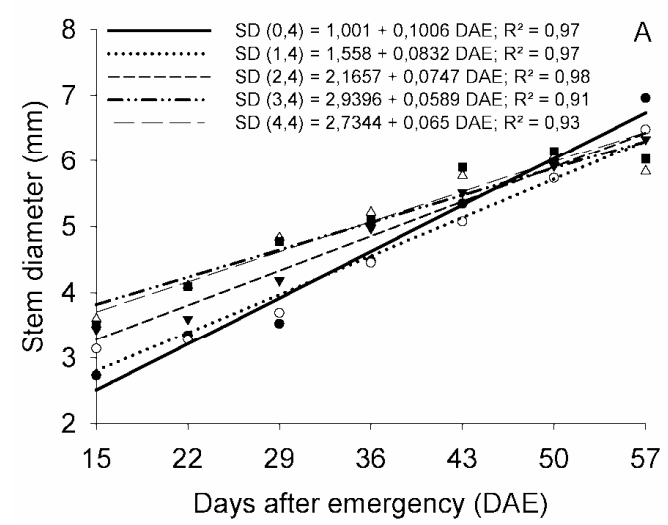

'Quarentinha' cultivar, had a decline in stem diameter under saline stress at 35 days after sowing (ANDRADE et al., 2013).

The highest stem diameters obtained with 400 and $800 \mathrm{~mL}$ plant $^{-1}$ week $^{-1}$ mixed biofertilizer doses are due to the nutritional availability of this fertilizer for the crop. The microbial and bioactive activity present in this input has the capacity to provide protection and resistance to the plant (GROVER et al., 2011). The stem growth increase provided by biofertilizers in saline environments was also observed in Arachis hypogaea L. and Passiflora edulis f. flavicarpa (SOUSA et al., 2012, OLIVEIRA et al., 2015).

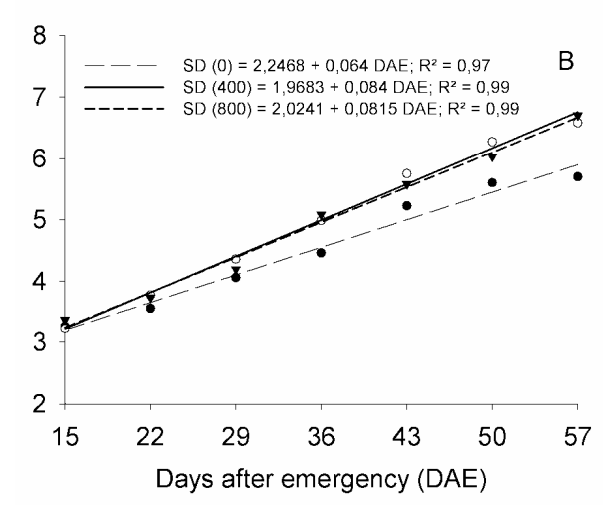

Figure 1. Regression analysis for stem diameter $(\mathrm{mm})$ of cowpea plants submitted to irrigation with different levels of salinized water (A) and biofertilizer doses (B).

The leaves number reduced with leaves number was 15.91 with $1.4 \mathrm{dS} \mathrm{m}^{-1}$ (Table 1 , increasing of saline water irrigation. The maximum Figure 2). 


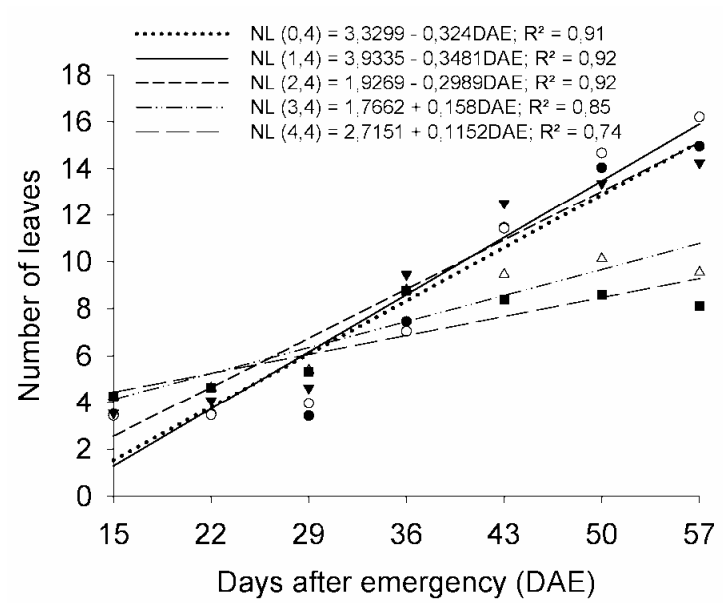

Figure 2. Number of cowpea leaves submitted to irrigation with different levels of salinized water.

The leaves number decrease with increasing irrigation water salinity probably occurred due to the sodium chloride accumulation in the cell walls and in the older leaves cytoplasm. At the same time, the vacuole sap can not accumulate more salt, reducing the concentration inside the cells, leading to rapid death and leaf fall (MUNNS, 2002). The leaf numbers reduction by saline stress impairs plant growth and development due to lower leaf area and net photosynthesis rate (GOMES et al., 2011; NUNES et al., 2012). The leaves number decreased in $V$. unguiculata plants irrigated with salt water, in soil with common bovine biofertilizer and enriched crab biofertilizer (SOUSA et al., 2014). The biofertilizer excess reduce plant biomass by toxicity could be the direct consequence of the chlorophyll synthesis inhibition and photosynthesis (KONG et al., 2017). Excessive salt and nitrogen amount from biofertilizer may cause decreased uptake of nutrient elements, inhibition of various enzyme activities,

induction of oxidative stress including alterations in enzymes of the antioxidant defense system and leaves fall (WINGLER; ROITSCH, 2008; ZIMMERMANN; ZENTGRAF, 2015). In addition to genetic control, senescence is regulated by joined actions of external (e.g., $\mathrm{N}$ availability, light) and internal (e.g., regulating metabolites, $\mathrm{C} / \mathrm{N}$ ratio) signals (BAO et al., 2015; KONG et al., 2017) Sugar regulation of leaf senescence is also dependent on plant $\mathrm{N}$ status and soil $\mathrm{N}$ content. Therefore, excessive $\mathrm{N}$ and the desynchronization of $\mathrm{N}$ application with crop demand will acelerate leaves fall.

The FMAP, DMAP, FRM and DRM were significantly influenced by irrigation water salinity and mixed biofertilizer, except for DRM, which was significantly influenced by the mixed biofertilizer. There was no interaction between the factors (Table 2).

Table 2. Summary of variance analysis for FMAP, DMAP, FMR, and DMR of cowpea plants submitted to irrigation with different levels of saline water and mixed biofertilizer doses

\begin{tabular}{llllll}
\hline Source of variation & GL & Mean squares & & \\
\cline { 3 - 6 } & & FMAP & DMAP & FRM & DRM \\
\hline Blocks & 3 & $1276.90796^{\text {ns }}$ & $9.86095^{\mathrm{ns}}$ & $9.04229^{\text {ns }}$ & $0.99187^{\text {ns }}$ \\
Salinity (a) & 4 & $4518.95910^{*}$ & $77.29303^{*}$ & $10.12492^{*}$ & $0.53663^{\text {ns }}$ \\
Error-a & 12 & 389.67810 & 15.08145 & 2.98314 & 0.44052 \\
Biofertilizer (b) & 2 & $3867.97993^{*}$ & $80.71499^{*}$ & $26.41949^{*}$ & $1.28499^{*}$ \\
Interaction - a x b & 8 & $361.12130^{\text {ns }}$ & $9.16537^{\text {ns }}$ & $4.49979^{\text {ns }}$ & $0.08366^{\text {ss }}$ \\
Error-b & 30 & 441.26835 & 9.91480 & 4.02946 & 0.15394 \\
Total & 59 & - & - & - & - \\
\hline
\end{tabular}

* significant at $5 \%$ by the $\mathrm{F}$ test; (ns) not significant by the F test; GL - Degree of freedom.

FMAP decreased linearly with increasing saline concentration of irrigation water (Figure 3A). The highest value of FMAP (69.15 g) was obtained in the control $\left(0.4 \mathrm{dS} \mathrm{m}^{-1}\right)$ and the lowest value
$(23.93 \mathrm{~g})$ in the highest salinity level was $4.4 \mathrm{dS} \mathrm{m} \mathrm{m}^{-1}$. The FMAP increased linearly with the mixed biofertilizer doses $\left(\mathrm{R}^{2}\right.$ 0.87), with higher value 

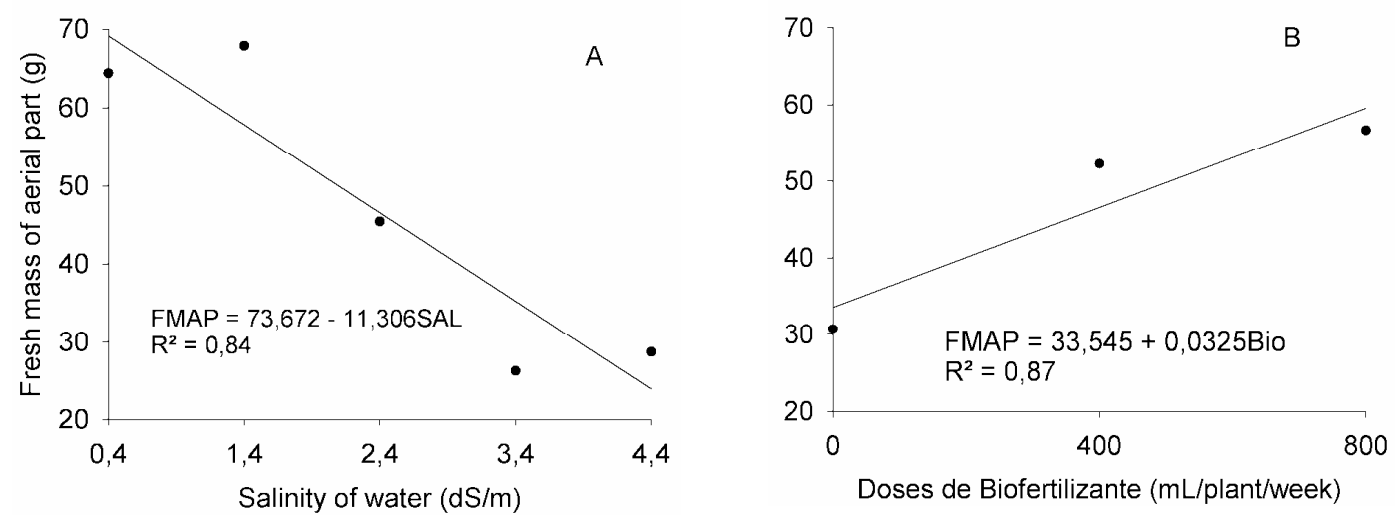

Figure 3. Fresh mass of aerial part ( $\mathrm{g}$ ) of cowpea plants submitted to irrigation with esulto f levels of salinized water (A) and mixed doses of biofertilizer (B).

The decrease in $V$. unguiculata plant growth is an energy metabolic cost reflection associated with an attempt to adapt the plant to salinity (DANTAS et al., 2002; MUNNS, 2002). The common bean lowest growth of an adaptive mechanism to the saline condition, so the plant maintains its vital activities, even to a limited extent (COELHO et al., 2013). The biofertilizer positive effect on the aerial part may be associated with the root growth stimulation by the phytohormones production, which allows the water roots uptake, improving plant nutrition and increasing nutrient availability (JOSKO et al., 2013).

DMAP decreased linearly with increasing irrigation water salinity $\left(\mathrm{R}^{2}=0.82\right)$ and increased linearly as a result of the increase in mixed biofertilizer doses $\left(\mathrm{R}^{2}=0.76\right)$ (Figure 4A-B).
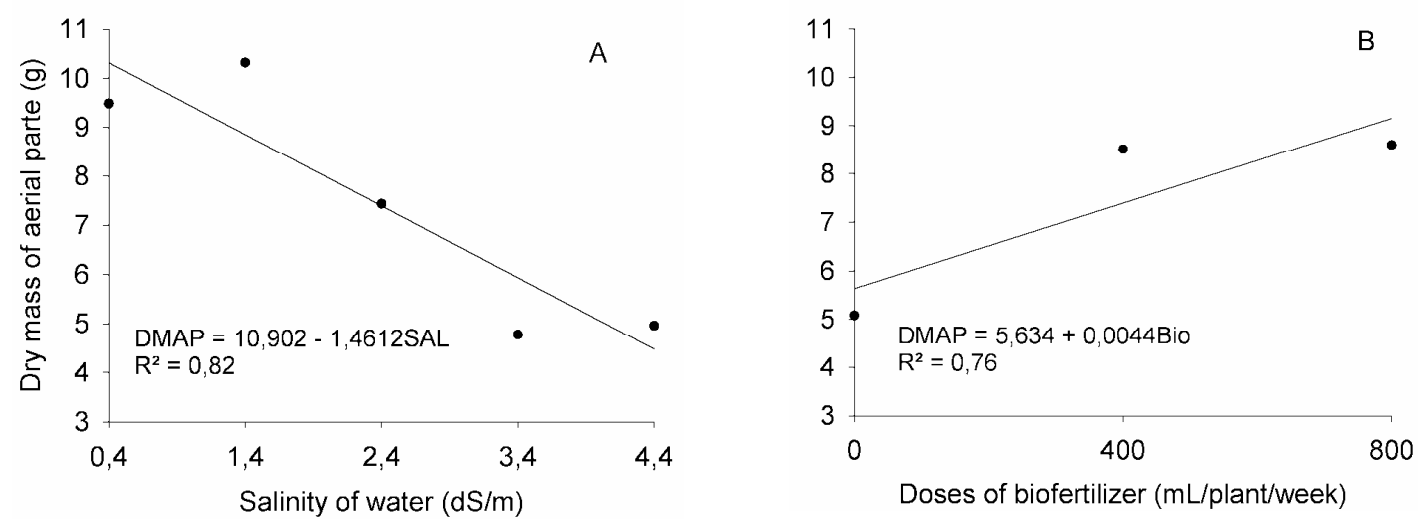

Figure 4. Dry mass of aerial part (g) of cowpea plants submitted to irrigation with different levels of saline water (A) and mixed doses of biofertilizer (B).

The saline concentration increase in the soil solution causes a decrease in dry mass, which consequently increases the osmotic pressure, decreasing the absorption and the water supply, which are one of the main factors for a dry matter or biomass production

(MACHADO;

SERRALHEIRO, 2017). The reduction in dry matter may be due to the stomatal closure caused by salinity that limits $\mathrm{CO}_{2}$ assimilation and inhibits leaf expansion, accelerating the mature leaves senescence, reducing the area destined to the photosynthetic process and the photoassimilates production (LACERDA et al., 2003). The dry mass increase of the aerial part with the use of mixed biofertilizer prove the attenuation effect of this compound in $V$. unguiculata plants under salt stress due to slow nutrients release of the biofertilizer (FACHINI et al., 2004), besides promoting the soil aggregation and porosity, retention and water infiltration in the soil (RODRIGUES et al., 2013). The dry aerial part biomass of vigna bean cultivated in two soils classes (French-sandy and loamy clay) artificially salinized reduced $64.5 \%$ and $60.7 \%$ (COELHO et al., 2013), similar to the data found in 
this research. The cultivar Quarentinha of $V$. unguiculata also had its dry biomass aerial part reduced by $66.94 \%$ with the increase of soil salinity irrigated with water at $5.0 \mathrm{dS} \mathrm{m}{ }^{-1}$ (LIMA et al., 2007), similar to the data found in this research.

The fresh root mass decreased with increasing salinity. The maximum fresh root mass value was $5.95 \mathrm{~g}$ for the salinity level $0.4 \mathrm{dS} \mathrm{m}{ }^{-1}$ (Figure 5A). The fresh root mass increased linearly with the mixed biofertilizer doses, reaching a maximum value of $6.01 \mathrm{~g}$ with the dose of $800 \mathrm{ml}$ plant $^{-1}$ week $^{-1}$ (Figure 5B).
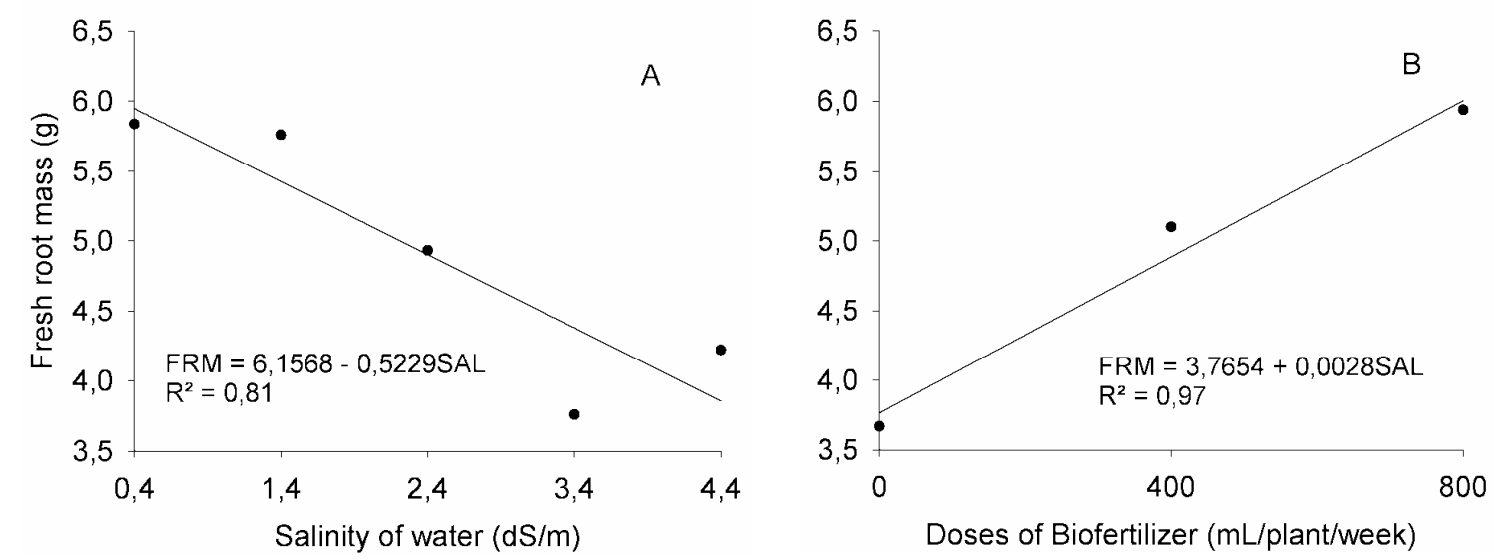

Figure 5. Fresh root mass (g) of cowpea plants submitted to irrigation with different levels of saline water (A) and mixed doses of biofertilizer (B).

The fresh root mass decrease by saline stress is associated with the ions accumulation that concentrate in the soil (SHRIVASTAVA; KUMAR, 2015). The soil salt concentration increase by irrigation reduced root growth and consequently the weight of this variable in $V$. unguiculata plants (SILVA et al., 2011). Reduction in root growth and elongation in Chenopodium quinoa was caused by high salt levels at various development stages, reducing the supply of photosynthates from the shoot and morphological changes in the root, which should not be considered as a simple growth reduction, but rather as an induced growth reorientation to avoid stress (PANUCCIO et al., 2014).

The fresh mass increase of the roots with the mixed biofertilizer application of demonstrates the imput effect attenuation and may be considered an important management strategy for $V$. unguiculata plants cultivated in saline environment. The application of biofertilizer in the soil can induce an increase in the osmotic adjustment to the plants by the organic solutes accumulation, promoting the water and nutrients absorption under saline stress, improving the conditions for emergence, vegetative growth and biomass production of plants (BAALOUSHA et al., 2006).
Dry mass of the root increased linearly with the mixed biofertilizer application, with a maximum value of $1.32 \mathrm{~g}$ in the dose $800 \mathrm{~mL}$ plant $^{-1}$ week $^{-1}$ (Figure 6). 


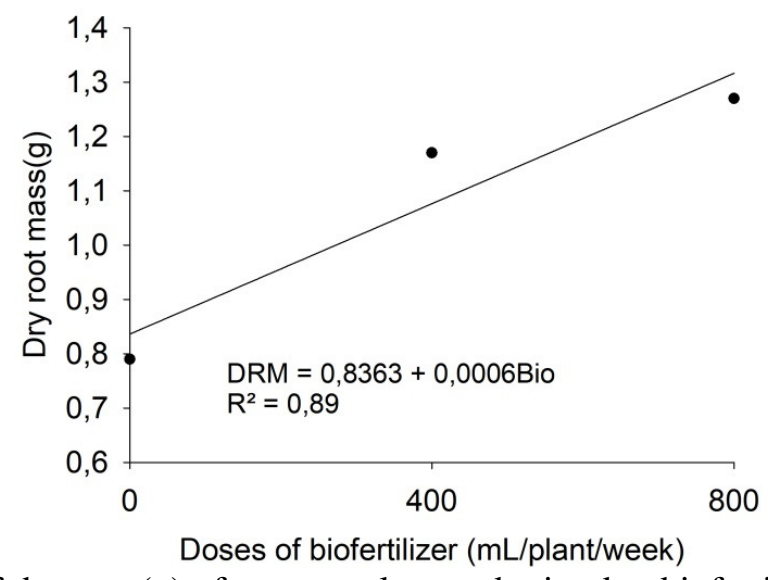

Figure 6. Dry mass of the root (g) of cowpea plants submitted to biofertilizer different doses.

The increased linearly of root dry mass with the mixed biofertilizer application on $V$. unguiculata irrigated with saline water levels, is related to the humic substances increase of, improving soil quality, providing a source of nutrients and increasing cation exchange capacity and nutrient availability (JINDO et al., 2012). Biofertilizers improve soil structure and water retention (OLMO et al., 2016), while improving biological properties favoring plant-microorganism interactions, increasing water and nutrient uptake by plants (HAMMER et al., 2014). Although it was not included in the scope of the present study, a larger nodules number of nitrogen-fixing bacteria and with a higher finer roots number were observed in the plants root system that received the mixed biofertilizer.

\section{CONCLUSIONS}

V. unguiculata cv. Canapu proved to be very sensitive to saline stress, its growth and development being affected from $1.4 \mathrm{ds} \cdot \mathrm{m}^{-1}$.

The use of mixed biofertilizer was able to minimize the effect of salinity in all analyzed variables, improving the growth and development of cowpea cv. Canapu, protecting from negative impacts of saline stress. The incorporation of mixed biofertilizer may be a promising strategy to improve crop growth and productivity in salt affected soils.

\section{ACKNOWLEDGMENTS}

To Conselho Nacional de Desenvolvimento Científico e Tecnológico (CNPq) and the Fundação Cearense de Apoio ao Desenvolvimento Científico e Tecnológico (FUNCAP) for financial resources.

RESUMO: Novas estratégias para aumentar o crescimento e a produtividade de plantas cultivadas em solos salinos representam prioridades na pesquisa. $\mathrm{O}$ experimento foi conduzido em vaso, para investigar o crescimento do Feijão-Caupi em resposta ao estresse salino sob a correção de um biofertilizante misto. Cinco níveis de salinidade da água de irrigação e três doses do biofertilizante misto foram testados, com quatro repetições cada nível. O biofertilizante misto foi capaz de minimizar o estresse salino. O aumento do nível de salinidade resultou em reduções no diâmetro do caule, número de folhas, biomassa da parte aérea e das raízes. $\mathrm{O}$ uso do biofertilizante misto minimizou o efeito da salinidade em todas as variáveis analisadas, melhorando o crescimento e desenvolvimento do feijão caupi, protegendo-o dos impactos negativos do estresse salino. O uso de biofertilizante misto pode ser uma opção para melhorar o crescimento da cultura e a produtividade em solos afetados por sais.

PALAVRAS-CHAVE: Estresse ambiental. Qualidade da água. Vigna unguiculata L. Walp. 


\section{REFERENCES}

ANDRADE, J. R.; MAIA JUNIOR, S. O.; SILVA, P. F.; BARBOSA, J. W. S.; NASCIMENTO, R.; SOUSA, J. S. Crescimento inicial de genótipos de feijão caupi submetidos a diferentes níveis de água salina.

Agropecuária Científica no Semiárido, Campina Grande, v. 9, n. 4, p. 38-43, 2013.

http://dx.doi.org/10.30969/acsa.v9i4.430

AYDIN, A.; KANT, C.; TURAN, M. Humic acid application alleviate salinity stress of bean (Phaseolus vulgaris L.) plants decreasing membrane leakage. African Journal of Agricultural Research, Nairobi, v. 7, n. 7, p. 1073-1086, 2012. https://doi.org/10.5897/AJAR10.274

BAALOUSHA, M.; HEINO, M. M.; LE COUSTUMER, B. K. Conformation and size of humic substances: effects of major cation concentration and type, $\mathrm{pH}$, salinity, and residence time. Colloids and surfaces A: physicochemical and engineering aspects, Amsterdam, v. 272, n. 1, p. 48-55, 2006.

https://doi.org/10.1016/j.colsurfa.2005.07.010

BAO, A.; ZHAO, Z.; DING, G.; SHI, L.; XU, F.; CAI, H. The stable level of glutamine synthetase 2 plays an important role in rice growth and in carbon-nitrogen metabolic balance. International Journal of Molecular Sciences, Basel, v. 16, n. 6, p. 12713-12736, 2015. https://doi.org/10.3390/ijms160612713

CALVO, P.; NELSON, L.; KLOEPPER, J. W. Agricultural uses of plant biostimulants. Plant and Soil, Dordrecht, v. 383, n. 1-2, p. 3-41, 2014. https://doi.org/10.1007/s11104-014-2131-8

CELENTANO, A.; BORGES, F. R. M.; MARINHO, A. B.; BEZERRA, F. M. L.; RODRIGUES, J. P. M.; PEREIRA, E. D. Parâmetros produtivos do girassol submetido à lâminas de irrigação na região do maciço de Baturité - CE. Revista Brasileira de Agricultura Irrigada, Fortaleza, v. 11, n. 1, p. 1213-1222, 2017. http://dx.doi.org/10.7127/rbai.v11n100570

COELHO, J. B. M.; BARROS, M. F. C.; BEZERRA NETO, E.; CORREA, M. M. Comportamento hídrico e crescimento do feijão vigna cultivado em solos salinizados. Revista Brasileira de Engenharia Agrícola e Ambiental, Campina Grande, v. 17, n. 4, p. 379-385, 2013. http://dx.doi.org/10.1590/S141543662013000400004

DANTAS, J. P.; MARINHO, F. J. L.; FERREIRA, M. M. M.; AMORIM, M. S. N.; ANDRADE, S. I. O.; SALES, A. E. Avaliação de genótipos de feijão-de-corda sob salinidade. Revista Brasileira de Engenharia Agrícola e Ambiental, Campina Grande, v. 6, n. 3, p. 425-430, 2002. https://doi.org/10.1590/S141543662002000300008

DU JARDIN, P. Plant biostimulants: definition, concept, main categories and regulation. Scientia horticulturae, Amsterdam, v. 196, p. 3-14, 2015. https://doi.org/10.1016/j.scienta.2015.09.021

FACHINI, E.; GALBIATTI, J. A.; PAVANI, L. C. Níveis de irrigação e de compostos de lixo orgânico na formação de mudas cítricas em casa de vegetação. Engenharia Agrícola, Jaboticabal, v. 24, n. 3, p. 578-588, 2004. http://dx.doi.org/10.1590/S0100-69162004000300010

GLICK B. R.; CHENG Z.; CZARNY J.; DUAN J. Promotion of plant growth by ACC deaminase-producing soil bacteria. European Journal of Plant Pathology, Dordrecht, v. 119, n. 3, p. 329-339, 2007.

https://doi.org/10.1007/s10658-007-9162-4

GOMES, K. R.; AMORIM, A. V.; FERREIRA, F. J.; FILHO, F. L.; LACERDA, C. F.; GOMES FILHO, E. Respostas de crescimento e fisiologia do milho submetido a estresse salino com diferentes espaçamentos de cultivo. Revista Brasileira de Engenharia Agrícola e Ambiental, Campina Grande, v. 15, n. 4, p. 365-370, 2011. https://doi.org/10.1590/S1415-43662011000400006 
GROVER, M.; ALI S. K. Z.; SANDHYA, V.; RASUL, A.; VENKATESWARLU, B. Role of microorganisms in adaptation of agriculture crops to abiotic stresses. World Journal of Microbiology and Biotechnology, Dordrecht, v. 27, n. 5, p. 1231-1240, 2011. https://doi.org/10.1007/s11274-010-0572-7

HALPERN, M.; BAR-TAL, A.; OFEK, M.; MINZ, D.; MULLER, T.; YERMIYAHU, U. The use of biostimulants for enhancing nutrient uptake. D.L. Sparks (Ed.). Advances in Agronomy, San Diego, v. 129, p. 141-174, 2015. https://doi.org/10.1016/bs.agron.2014.10.001

HAMMER, E. C.; BALOGH-BRUNSTAD, Z.; JAKOBSEN, I.; OLSSON, P. A.; STIPP, S. S.; RILLIG, M. C. A mycorrhizal fungus grows on biochar and captures phosphorus from its surfaces. Soil Biology and Biochemistry, Oxford, v. 77, p. 252-260, 2014. https://doi.org/10.1016/j.soilbio.2014.06.012

JAMIL, A.; RIAZ, S.; ASHRAF, M.; FOOLAD, M. R. Gene expression profiling of plants under salt stress. Critical Reviews Plant Sciences, London, v. 30, n. 5, p. 435-458, 2011.

https://doi.org/10.1080/07352689.2011.605739

JINDO, K.; MARTIM, A. S.; NAVARRO, E. C.; PÉREZ-ALFOCEA, F.; HERNANDEZ, T, GARCIA, C.; AGUIAR, N. O.; CANELLAS, L. P. Root growth promotion by humic acids from composted and noncomposted urban organic wastes. Plant and Soil, Dordrecht, v. 353, n. 1-2, p. 209-220, 2012. http://dx.doi.org/10.1007/s11104-011-1024-3

JOSKO, I.; OLESZCZUK, P.; PRANAGAL, J.; LEHMANN, J.; XING, B.; CORNELISSEN, G. Effect of biochars, activated carbon and multiwalled carbon nanotubes on phytotoxicity of sediment contaminated by inorganic and organic pollutants. Ecological Engineering, Oxford, v. 60, p. 50-59, 2013.

https://doi.org/10.1016/j.ecoleng.2013.07.064

KONG, L.; XIE, Y.; HU. L.; SI, J.; WANG, Z. Excessive nitrogen application dampens antioxidant capacity and grain filling in wheat as revealed by metabolic and physiological analyses. Scientific Reports, Oxford, v. 7, n. 43363, p.1-14, 2017. https://doi.org/10.1038/srep43363

KÖPPEN, W.; GEIGER, R. Klimate der Erde. Gotha: Verlag Justus Perthes. 1928.

LACERDA, C. F.; CAMBRAIA, J.; CANO, M. A. O.; RUIZ, H. A.; PRISCO, J. T. Solute accumulation and distribution during shoot and leaf development in two sorghum genotypes under salt stress. Environmental and Experimental Botany, Paris, v. 49, n. 2, p. 107-120, 2003. https://doi.org/10.1016/S0098-8472(02)000643

LIMA, C. J. G. S.; OLIVEIRA, F. A.; MEDEIROS, J. F.; OLIVEIRA, M. K. T.; ALMEIDA JÚNIOR, A. B. Resposta do feijão caupi a salinidade da água de Irrigação. Revista Verde de Agroecologia e

Desenvolvimento Sustentável, Mossoró, v. 2, n. 2, p. 79-86, 2007.

MACHADO, R. M. A.; SERRALHEIRO, R. P. Soil Salinity: Effect on Vegetable Crop Growth. Management Practices to Prevent and Mitigate Soil Salinization. Horticulturae, Basel, v. 3 n. 30, p. 1-13, 2017. https://doi.org/10.3390/horticulturae3020030

MUNNS R. Tansley review: genes and salt tolerance: bringing them together. New Phytologist, Cambridge, v. 167, p. 645-663, 2005. http://dx.doi.org/10.1111/j.1469-8137.2005.01487.x

MUNNS, R. Comparative physiology of salt and water stress. Plant, Cell and Environment, New York, v. 25, n. 2, p. 239-250, 2002. https://doi.org/10.1046/j.0016-8025.2001.00808.x

MUSCOLO, A.; PANUCCIO, M. R.; HESHEL, A. Ecophysiology of Pennisetum clandestinum: a valuable salt tolerant grass. Environmental and Experimental Botany, England, v. 92, p. 55-63, 2013.

https://doi.org/10.1016/j.envexpbot.2012.07.009 
NUNES, J. C.; CAVALCANTE, L. F.; LIMA NETO, A. J.; REBEQUI, A. M.; DINIZ, B. L. M. T.; GHEYI, H. R. Comportamento de mudas de nim à salinidade da água em solo não salino com biofertilizante. Revista Brasileira de Engenharia Agrícola e Ambiental, Campina Grande, v. 16, n. 11, p. 1152-1158, 2012. http://dx.doi.org/10.1590/S1415-43662012001100002

OLIVEIRA, F. A.; LOPES, M. Â. C.; SILVA SÁ, F. V.; NOBRE, R. G.; MOREIRA, R. C. L.; DE ANDRADE SILVA, L.; PAIVA, E. P. Interação salinidade da água de irrigação e substratos na produção de mudas de maracujazeiro amarelo. Comunicata Scientiae, Bom Jesus, v. 6, n. 4, p. 471-478, 2015. http://dx.doi.org/ $10.14295 /$ cs.v6i4.982

OLMO, M.; VILLAR, R.; SALAZAR, P.; ALBURQUERQUE, J. A. Changes in soil nutrient availability explain biochar's impact on wheat root development. Plant and soil, Dordrecht, v. 399, n.1-2, p. 333-343, 2016. http://dx.doi.org/10.1007/s11104-015-2700-5

PANUCCIO, M. R.; JACOBSEN, S. E.; AKHTAR, S. S.; MUSCOLO, A. Effect of saline water on seed germination and early seedling growth of the halophyte quinoa. AoB Plants, Oxford, v. 6[plu047]. https://doi.org/10.1093/aobpla/plu047

PRAZERES, S. S.; LACERDA, C. F.; BARBOSA, F. E. L.; AMORIM, A.V.; ARAUJO, I. C. S.; CAVALCANTE, L. F. Crescimento e trocas gasosas de plantas de feijão-caupi sob irrigação salina e doses de potássio. Revista Agro@mbiente On-line, Boa Vista, v. 9, n. 2, p. 111-118, 2015. http://dx.doi.org/10.18227/1982-8470ragro.v9i2.2161

QADOS, A. M. S. A. Effect of salt stress on plant growth and metabolism of bean plant Vicia faba (L.). Journal of the Saudi Society of Agricultural Sciences, Saudi Arabia, v. 10, n. 1, p. 7-15, 2011. https://doi.org/10.1016/j.jssas.2010.06.002

RHOADES, J. D.; KANDIAH, A.; MASHALI, A. M. Uso de águas salinas para produção agrícola. (Estudos da FAO - Irrigação e Drenagem, 48, Revisado), Campina Grande: UFPB. 2000. 117 p.

RODRIGUES, J. F.; REIS, J. M. R.; REIS, M. A. Utilização de estercos em substituição a adubação mineral na cultura do rabanete. Revista Trópica: Ciências Agrárias e Biológicas, Chapadinha, v. 7, n. 2, p.160-168, 2013.

SHAHBAZ, M.; ASHRAF, M. Improving salinity tolerance in cereals. Critical Reviews in Plant Sciences, Boca Raton, v. 32, n. 4, p. 237-249, 2013. http://dx.doi.org/10.1080/07352689.2013.758544

SHRIVASTAVA, P.; KUMAR, R. Soil salinity: a serious environmental issue and plant growth promoting bacteria as one of the tools for its alleviation. Saudi Journal of Biological Sciences, Saudi Arabia, v. 22, n. 2, p. 123-131, 2015. https://doi.org/10.1016/j.sjbs.2014.12.001

SIDARI, M.; SANTONOCETO, C.; ANASTASI, U.; PREITI, G.; MUSCOLO, A. Variations in four genotypes of lentil under NaCl-salinity stress. American Journal of Agricultural and Biological Science, Dubai, v. 3, n.1, p. 410-416, 2008. http://dx.doi.org/10.3844/ajabssp.2008.410.416

SILVA, F. L. B.; LACERDA, C. F.; SOUSA, G. G.; NEVES, A. L. R.; SILVA, G. L.; SOUSA, C. H. C. Interação entre salinidade e biofertilizante bovino na cultura do feijão-de-corda. Revista Brasileira de Engenharia Agrícola e Ambiental, Campina Grande, v. 15, n. 4, p. 383-389, 2011. https://doi.org/10.1590/S1415-43662011000400009

SOUSA, G. G.; AZEVEDO, B. M.; MESQUITA, J. B. R.; VIANA, T. V. A. Características agronômicas do amendoinzeiro sob irrigação com águas salinas em solo com biofertilizantes. Revista Agro@mbiente On-line, Boa Vista, v. 6, n. 2, p. 124-132, 2012. http://dx.doi.org/10.18227/1982-8470ragro.v6i2.708 
SOUSA, G. G.; VIANA, T. V. A.; LACERDA, C. F.; AZEVEDO, B. M.; SILVA, G. L.; COSTA, F. R. B. Estresse salino em plantas de feijão-caupi em solo com fertilizantes orgânicos. Revista Agro@mbiente Online, Boa Vista, v. 8, n. 3, p. 359-367, 2014. http://dx.doi.org/10.18227/1982-8470ragro.v8i3.1824

SOUTO, A. G. L.; CAVAlCANTE, L. F.; NASCIMENTO, J. A. M.; MESQUITA, F. O.; LIMA NETO, A. J. Comportamento do noni à salinidade da água de irrigação em solo com biofertilizante bovino. Irriga, Botucatu, v. 18, n. 3, p. 442-453, 2013. http://dx.doi.org/10.15809/irriga.2013v18n3p442

VAN OOSTEN, M. J.; PEPE, O.; DE PASCALE, S.; SILLETTI, S.; MAGGIO, A. The role of biostimulants and bioeffectors as alleviators of abiotic stress in crop plants. Chemical and Biological Technologies in Agriculture, Portici, v, 4, n. 5, p. 1-12, 2017. https://doi.org/10.1186/s40538-017-0089-5.

WINGLER, A.; ROITSCH, T. Metabolic regulation of leaf senescence: interactions of sugar signalling with biotic and abiotic stress response. Plant Biology, Amsterdam, v. 10, n. 1, p. 50-62, 2008.

https://doi.org/10.1111/j.1438-8677.2008.00086.x

YAKHIN, O.; LUBYANOV, A. A.; YAKHIN, I. A.; BROWN, P. Biostimulants in plant science: a global perspective. Frontiers in Plant Science, Rockville Pike, v. 7, n. 2049, p. 1-32, 2017.

https://doi.org/10.3389/fpls.2016.02049

ZAHIR, Z. A.; MUNIR, A.; ASGHAR, H. N.; ARSHAD, M.; SHAHAROONA, B. Effectiveness of rhizobacteria containing ACC-deaminase for growth promotion of peas (Pisum sativum) under drought conditions. Journal of Microbiology and Biotechnology, Dordrecht, v. 18, n. 5, p. 958-963, 2008.

ZHU, J. K. Plant salt stress. In: O'Daly A, editor. Encyclopedia of life sciences. Chichester: John Wiley \& Sons, p.1-3, 2007. http://dx.doi.org/10.1002/9780470015902.a0001300.pub2.

ZIMMERMANN, P.; ZENTGRAF, U. The correlation between oxidative stress and leaf senescence during plant development. Cellular \& Molecular Biology Letters, Wrocław, v. 10, n. 3, p. 515-534, 2005. 